\author{
Abdurrazzaq Hesamifar, ${ }^{1}$ Alinaqi Baqershahi ${ }^{2}$ \\ Imam Khomeini International University, Faculty of Humanities, Qazvin, \\ Soleymani Blvd., 34149 16818, Iran \\ ${ }^{1}$ ahesamifar@hum.ikiu.ac.ir, ${ }^{2}$ baghershahi@hum.ikiu.ac.ir
}

\title{
Wittgenstein's Tractatus and the Descriptiveness of Elementary Propositions
}

\begin{abstract}
According to Wittgenstein, the elementary propositions cannot be analysed into any further proposition. In T. 4.22, Wittgenstein speaks of names as the constituents of the elementary proposition. What does he mean by names? He does not mean proper names because such names refer to complex things. According to him, "a name means an object" (T. 3.203), "objects are simple" (T. 2.02), and the "analysis of propositions must bring us to the elementary propositions which consist of names in immediate combination" ( $T$, 4.221). There is a dispute over the descriptiveness of elementary propositions. The picture theory, accepted by the early Wittgenstein, tells us that it is necessary to refer to some existent objects for a proposition to have a meaning. However, in Tractatus, there is no exemplification for the elementary propositions and their constituents, i.e. objects. Thus, the equation between the states of affairs and the elementary propositions or between objects and proper names may turn out to be just a logical equation without any empirical content, despite the positivistic reading of Tractatus promoting empiristic interpretation. This paper tries to show that by drawing on the picture theory the elementary propositions should describe something in the real world. Nevertheless, since what is depicted by them cannot be designated and referred by any ostensive definition, except in the logical sense of word, the way in which they depict reality is doubtful and controversial.
\end{abstract}

Keywords

elementary proposition, complex proposition, object, states of affairs, name, situation

\section{Introduction}

Regarding the Tractatus Logico-Philosophicus - henceforth Tractatus - there are some questions concerning the descriptiveness of the elementary propositions, with which interpreters of the book have concerned themselves. If the main function of language is to depict reality and all complex propositions are reduced to the elementary propositions, then the latter should depict reality. However, is there any example for elementary propositions? How can we refer to any state of affairs as depicted by an elementary proposition? Is there anything that can be shown as the referent of a name? In Tractatus, does object just refer to a logically supposed thing or its reference is an observable thing which can be touched in the experience? Which sensible thing is the referent of a name and which observation statement can be regarded as an elementary proposition? This paper tries to find some answers to these questions. It will show how can we solve some inconsistencies between Wittgenstein's ideas.

Between different readings of the book, the main reading that connects the book's content with experimental knowledge was proposed by the philosophers of Vienna Circle, who have held the doctrine of verificationism. According to this doctrine, it is necessary for any meaningful proposition to be 
empirically verifiable. ${ }^{1}$ It can be regarded as the positivistic interpretation of the picture theory which is in the heart of the Tractatus. In his Language, Truth and Logic, A. J. Ayer distinguished between two meanings of the term verifiable: the strong sense of the word means that the truth of a proposition can be conclusively proved in experience, and the weak sense of the word means that a proposition is verifiable when its probability can be shown by experience. Ayer says that all empirical propositions are hypotheses that are continually subjected to further experience, and it is possible to be refuted by further experience. Because of this, "the only sense in which any proposition could conceivably be verified" is the weak sense of verifiable, and the strong sense of it has no application. Furthermore, the propositions that can be verified conclusively are only the basic propositions that refer to a single experience's content. This kind of propositions are incorrigible (Ayer, 1971, pp. 176-177). For verificationism, R. Carnap stated the following:

"The meaning of a statement lies in the method of its verification. A statement asserts only so [as] much as is verifiable with respect to it. Therefore a sentence can be used only to assert an empirical proposition, if indeed it is used to assert anything at all." (Carnap, 1959 [1932], p. 76)

Relying on the principle of verification, Logical Positivists held that only observable propositions are scientific, and therefore, meaningful propositions, and any other kinds of propositions, such as metaphysical propositions and ethical propositions which have nothing to do with observation statements, have no meaning. Only inductive metaphysics (for example, Democritus' atomism) is scientifically meaningful (Blumberg \& Feigl, 1931, p. 293).

Vienna Circle was influenced by the Tractatus, to the extent that in its meetings, it was being read aloud and sentence by sentence (Menger, 1982, p. 86), but the principle of verification is not contained in Tractatus. It was later formulated by Wittgenstein, in his discussions with Schlick. It seems that this principle, at least among logical positivists, is under the impact of their reading of the book and their understanding of the picture theory. The expression of the picture theory in the Tractatus is what has been said about the main function of language as representing and depicting reality - "words" and "propositions" depict "objects" and "states of affairs". If the positivistic point of view is right, then how can we presume to justify the representative function of language? If, as it will be shown in this paper, there is no referable entity that can be regarded as the referent of the word "object", how can the propositions related to certain objects, represent and describe them? If the words object, states of affairs and situation are used to give a logical analysis of the real world and accordingly have just logical content without referring to any observable thing, then how can we assert that they depict real things and facts?

G. E. M. Anscombe claimed that the best-known thesis of the Tractatus is probably the nonsensicality of "metaphysical" propositions, and that just the propositions of natural science are sayable (N. 6.53). She adds that the method of criticism against metaphysical propositions adopted by the Vienna Circle and Ayer was that since this kind of propositions cannot be verified or falsified by sense-observations, they are senseless. Then she refers to some difficulties about ascribing this doctrine to the Tractatus. For example, there is no mention of sensible verification in the book (Anscombe, 1959, p. 150). The problem, strictly speaking, is whether the Tractatus is a book written to give an empirical account of all propositions or its target was to give a meta- 
physical analysis of all propositions. In this regard, there are at least two entirely opposing readings of it. ${ }^{2}$ The metaphysical reading regards it as a work containing some claims about the nature of a language-independent reality and providing a speculative account of the relation between language and the independent reality and what is necessary for language to represent the world. Most of the early commentators of Tractatus, notably Ramsey, Russell, Black, Anscombe, Malcolm, Pears and Hacker, subscribed to this interpretation. The second reading is the therapeutic reading, according to which the main goal of the book was to unfold a kind of therapeutic strategy. According to this interpretation, the metaphysical pronouncements of the book, made from a philosophical perspective, are nonsensical, and consequently, this philosophical perspective is an illusion. The prominent advocates of this interpretation are Cora Diamond, James Conant, Tom Ricketts, and Warren Goldfarb (McGinn, 1999, pp. 491-492).

Marie McGinn puts forward a third interpretation as a synthesis of the two aforementioned approaches and calls it the elucidatory or clarificatory reading. This interpretation, she argues, combines the advantages of both and is immune from their disadvantages:

\footnotetext{
"An interpretation which avoids the suggestion that there are ineffable truths about reality, but which allows that there is something behind Wittgenstein's remarks; which permits these remarks to fall away completely, but which allows that the remarks accomplish something important; which avoids committing Wittgenstein to any metaphysical doctrines, but which does not fall into the paradox of self-destruction." (McGinn, 1999, pp. 496-497)
}

In this paper, the first reading of the book is advocated and taken up to assert that the picture theory in the Tractatus should be regarded as a logical or maybe a metaphysical theory. Keeping this view in mind, the authors disagree with the attitude of logical positivism that explicitly gives an empiricist interpretation of the picture theory. Moreover, following this view, positivists proceed to draw out the principle of verification. It is felt that the positivistic interpretation of the Tractatus can be added to the foregoing readings as the fourth reading, and it can be called the empiricist reading; because logical positivists regarded Wittgenstein as an anti-metaphysical fellow-traveller and a consistent empiricist. Under their phenomenalistic and empiricistic reading, the objects which atomic facts are composed of should be identified with sense-data. Nevertheless, in the 1960s, positivist readings of the book fell in disrepute. We agree with Alfonso García Suárez, who claims that "Wittgenstein's texts and testimonies do not support the view that Tractatus objects are items given in immediate experience" (Suárez, 2014, pp. 29-30).

Anscombe says: "The influence of the Tractatus produced logical positivism, whose main doctrine is "verificationism'." (Anscombe, 1959, p. 152) By considering Moritz Schlick's essay, Meaning and Verification, she tries to show how logical positivism was generated by the Tractatus, nevertheless she thinks that these two philosophies are incompatible.
James Conant and Silver Bronzo speak of the current controversy between two major parties in interpreting the book. The old and traditional reading and the resolute and revolutionary one. And they refer to a third reading which is somewhere in the middle between those two extremes. Main proponents of the resolute reading are Cora Diamond and James Conant (Conant \& Bronzo, 2017, p. 175). 


\section{Simple Objects}

Regarding the world, Wittgenstein uses some German words: Gegenstand (object), Sachverhalt (atomic facts ${ }^{3}$ or states of affairs), ${ }^{4}$ Tatsache (facts or situations), Ding (thing) and Sache (entity). ${ }^{5}$ Concerning language, his words are: Name (name), Elementarsatz (elementary propositions or sentences) and Satz (propositions).

Some interpreters believe that Wittgenstein takes object to be equivalent to Sache (entity) or Ding (thing). Things is used in the Tractatus only when it is combined with some other things to form atomic facts (Morris, 2008, p. 32).

In T. 2.0232 it is said, implicitly, that since qualities disappear altogether, the objects have no qualities; nevertheless, they have properties. Property is used in the book in a broad sense that covers relations. These properties have been divided into internal and external properties (T. 2.01231, 2.0233, 4.023) sometimes called formal and material properties (T. 2.0231). A material property of an object is that it stands in a certain relation to a second object and a formal property of an object is that it is possible for it to stand in a certain relation to a second object (Keyt, 1963, pp. 14-15). A short list of the main properties of objects in the Tractatus has been restated correctly by Pasquale Frascolla as follows (Frascolla, 2004, pp. 370-371):

1. objects are the substance of the world, in the sense that they subsist independently of what is the case (T. 2.024);

2. every object is, as it were, placed in the space of states of affairs, which can be thought of as empty (T. 2.013);

3. objects are colourless (T. 2.0232);

4. space, time and colour are forms of objects (T. 2.0251);

5. objects are simple, i.e. lack proper parts (T. 2.02);

6. two objects of one and the same logical form are distinguished only by their being different, i.e. formal indistinguishability does not entail identity (T. 2.0233).

In relation to the objects being simple, Wittgenstein says:

"Objects form the substance of the world; therefore they cannot be compound." (T. 2.021)

"Substance is what exists independently of what is the case." (T. 2.024)

Assimilating these expressions to Aristotle's concept of substance, Morris restates Wittgenstein's words as follows:

"A Substance is something which remains the same thing through changes." (Morris, 2008, p. 40)

Despite this view, Keyt thinks that "Wittgenstein's objects turn out to resemble Plato's Forms more than Aristotle's concrete individual" (Keyt, 1963, p. 18). However, it seems that Wittgenstein's concept of objects can be assimilated to Aristotle's concept of substance rather than Plato's concept of Forms; because, in Wittgenstein's point of view, the objects belong to this world, and there is no transcendent world like the world of Plato's Forms in which they are located. The properties of objects are like the properties of substances.

Jan Ludwig says that T. 2.02, which states "Objects are simple.", together with T. 2.021a, which states "Objects make up the substance of the world.", include a claim that lies at the heart of Wittgenstein's logical atomism and Tractatus. He then explicated that some commentators, like G. E. M. Anscombe, James Griffin, Julius Weinberg, E. D. Klemke, Max Black and George 
Pitcher, have regarded T. 2.0211-2.0212 as containing an argument for the existence of simple objects. Some of them tried to identify simple objects with substance but their arguments for that identification are not justified or they are, at best, incomplete. Their arguments need an additional argument to prove that, if the world has a substance, then it must consist of simple objects. To illustrate his opinion, Ludwig sayed that the argument at T. 2.0211-2.0212 can be interpreted either as an argument on the necessity of world having a substance or on the necessity of the existence of simple objects that constitute the substance of the world. The accounts of the argument for logical atomism all tend to support the latter interpretation; but they need an additional argument which justifies the identification of substance with simple objects (Ludwig, 1976, pp. 307-311).

However, there are some differences between Wittgenstein's remarks on "simples" in his early works: Prototractatus, Notebooks and Tractatus. The first use of the word simple comes in the Notebooks in April 1915:

"It always seems as if there were something that one can regard as a thing and on the other hand real simple things." (N. 43, 25.4.15)

In this book, Wittgenstein presented a sort of realistic view which led him to regard naming as a direct relation between a name and an independently existing object.

"By my correlating the components of the picture with objects, it comes to represent a situation and to be right or wrong." (N. 33-34, 26.11.14)

Wittgenstein does not use the notion name just for simple things. In some remarks, he is tempted to speak of the possibility that a name - a logically simple sign - stands for a compound thing:

"It is quite clear that I can in fact correlate a name with this watch just as it lies here ticking in front of me, and that this name will have reference outside any proposition in the very sense I have always given that word, and I feel that that name in a proposition will correspond to all the requirements of the names of "simple objects'." (N. 60, 15.6.15)

Wittgenstein thinks that the designation of compound spatial objects by means of names seems to be more than a trick of language, and we quite intuitively designate those objects by means of names (N. 47, 13.5.15). He says:

"When I say " $x$ ' has reference' do I have the feeling: 'It is impossible that ' $x$ ' should stand for, say, this knife or this letter?' Not at all, on the contrary.” (N. 49, 19.5.15)

Like Russell, Wittgenstein thinks of naming as a direct correlation between a sign, say name, and the thing that it signifies, and from this, we cannot conclude that name signifies just a simple thing. We should confirm that the concept of name is used for compound things as well (McGinn, 2007, p. 203). In addition, Wittgenstein agrees with Russell that although terms like "Piccadilly" and "Socrates" are counted as proper names in ordinary discourse, they

3

Ogden's translation.

4

Pear's \& McGuinnes's translation.

David Weissman shows why he thinks that "existing state of affairs" and "possible state of affairs" are compatible translations of
Sachverhalt and Tatsache. He argues that since Tatsachen are only complexes (truth functions) of Sachverhalte (T. 2.034; 4.2211), Sachverhalte may be conceived as existing atomic states of affairs, and because Tatsachen are described as facts (T. 2), Sachverhalte will also be known as atomic facts (Weissman, 1967, pp. 475-476). 
are not really logically proper names. They are, in fact, abbreviated definite descriptions (Russell, 1956, p. 253, 331).

In Notebooks, Wittgenstein tried to explain why he says that there is no complex object and all objects are simple. He says that when we say "complex objects do not exist", we mean that in a proposition we can speak of its being complex when we can make it clear how the object in it is composed and the sense of the proposition will appear when it is divided into its simple components. He concluded:

"When the sense of the proposition is completely expressed in the proposition itself, the proposition is always divided into simple components - no further division is possible and an apparent one is superfluous - and these are objects in the original sense." (N. 63, 17.6.15)

There are some ideas in the Notebooks which confirm the realistic interpretation of the Tractatus:

a) direct correlation between a name and an object;

b) a name has reference outside any proposition;

c) the analysis uncovers a complexity that is there, in an independently constituted reality (McGinn, 2007, p. 205).

The point is that what has been cited from the Notebooks is not mentioned in the Prototractatus and the Tractatus. In these two books, Wittgenstein says that if names had meaning both when combined in propositions and outside them we cannot guarantee that in both cases they really had the same meaning:

"It seems to be impossible for words to appear in two different roles; by themselves, and in propositions.” (P. 2.0122; cf. T. 2.0122)

Moreover, in these two books, there is no mention of the ideas of correlation between names and objects and of names having reference outside any proposition. At that time, it was held that a name is identifiable as a name only in so far as it is a logical constituent of a proposition. So the question of whether or not a name can stood for a compound thing disappears, and the main problem now seems to be changed:

"A complex can be given only by its description, which will be right or wrong." (P. 3.20105; T. 3.24)

Thus, only by means of a proposition, right or false, a complex can be represented, and "what can be named cannot be complex: What is complex is given only by its description which will be true or false" (McGuinn, 2007, pp. 205-206).

In the Prototractatus and the Tractatus, Wittgenstein did not discuss the idea of the sense of a proposition and the idea that in analysis we want to find a proposition which is as complex as its meaning is, despite the Notebooks in which he speaks of them:

"The sense of the proposition must appear in the proposition as divided into its simple components." (N. 63, 17.6.15)

"The demand for simple things is the demand for definiteness of sense." (N. 63, 18.6.15)

The aim of analysis is described in the Tractatus as follows:

"In a proposition a thought can be expressed in such a way that elements of the propositional sign correspond to the objects of thought. I call such elements 'simple signs' and such a proposition 'completely analysed'." (T. 3.2-3.20) 
It is held that after writing Notebooks, when Wittgenstein was going to write the first draft of Tractatus, he was changing his view about simples. Furthermore, some remarks in the Notebooks show that he was aware of the tension in his pre-Tractatus concept of simples (McGinn, 2007, p. 207):

"It keeps no looking as if the question 'are there simple things?' made sense. And surely this question must be nonsense!” (N. 45, 5.5.15)

"It is, therefore, impossible that the constituents of states of affairs for which names stand should be describable by means of propositions that can be compared with reality for truth or falsity; whatever is describable by means of a proposition is something that can either exist or fail to exist, namely, a state of affairs." (McGinn, 2007, p. 212)

Wittgenstein called the constituents of states of affairs which are at the same time constituents of the meaning of simple names, objects:

"Objects can only be named. Signs are their representatives. I can only speak about them: I cannot put them into words. Propositions can only say how things are, not what they are." (T. $3,221)$

According to McGinn's interpretation, Wittgenstein's concept of simple name does not show a version of realism in which names make a direct link between language and the world. He says that the object is not something that exists over and against language in an independent or transcendental realm. It is what we grasp when we grasp the meaning of the name, i.e. when we grasp the contribution that the name makes to determine the sense of a class of propositions. The most plausible examples of the simple constituents of elementary propositions are names of spatial or material points, colours, temporal points, etc., and functions of these (McGinn, 2007, pp. 213-214).

Besides, it is thought that

“... what objects there are is a nonempirical, nonlogical matter. It is an empirical matter what configurations of objects are actual. It is a logical matter what configurations of objects are possible. But what objects there are to be configured is neither." (Keyt, 1963, p. 18)

But in spite of these views, it seems that there are no examples for simple constituents of elementary propositions, and it seems that they are just logical hypotheses or, say, logical atoms of elementary propositions. If we present any ostensive definition for the components of elementary propositions and refer to some entities like material points and colours as examples of those components, we will find them not simple but complex, and in fact, in the realm of perception, we have no access to any simple thing.

\section{Elementary Propositions}

As it has been mentioned, in order to speak about the elementary propositions, Wittgenstein used the German term Elmentarsatz. The word Satz denotes, firstly, the idea of a written or spoken declarative sentence, and secondly, the idea of the meaning or thought expressed in a written or spoken sentence. Wittgenstein uses Satz to indicate a sentence, or sentence type, as opposed to the meaning of what comes between sentence and fact (Peterson, 1990, p. 192). In the Tractatus and regarding Elmentarsatz, Wittgenstein says:

"An elementary sentence consists of names. It is a nexus, a concatenation of names." (T. 4.22)

Here, Wittgenstein deals with names that are syntactic entities and not with meanings; since the word Satz is reduced to Elmentarsatz, Peterson concludes 
that Tractarian Satz are syntactic entities and are sentences rather than meanings of sentences (Peterson, 1990, p. 192). The word Elmentarsatz has been translated by some interpreters as "elementary proposition", and by some others as "elementary sentences". ${ }^{6}$ Although in the ordinary language Satz is used in both of those meanings, it seems that the first translation of the word is better because one of the differences between a proposition and a sentence is that the former is often dealt with in logic while the latter in literature. Since in the Tractatus Wittgenstein would like to be regarded as a logician, it can be said that, by using the word, he means "proposition" rather than "sentence". Nevertheless, some interpreters believe that the syntactic use of the word, that is "sentence", is more prevalent in Tractatus. The proposition expressed in a (meaningful declarative) sentence is the Sinn, or sense, of that sentence; hence Wittgenstein has enough tools in Tractatus to draw the distinction when he needed it. Different Sätze can have the same Sinn.

In his book on Wittgenstein, George Pitcher says that in the Tractatus, Wittgenstein had used the term Satz in two senses: proposition and sentence. When he used it as something capable of being true or false (e.g. T. 4.06, 4.25 and 4.26), he meant proposition, and when he spoke of it as a composition of words (e.g. T. 3.141), he meant sentence. But it is obvious that his interest was much more "in what sentences are used to assert; i.e. in propositions than in the sentences themselves" (Pitcher, 1964, pp. 28-30). Pitcher tried to show why he prefers "proposition" as the better translation for Satz. In order to point out the difference between propositions and sentences, he says:

"Propositions are the thoughts or ideas which sentences can be used to express. Sentences are composed of words in accordance with syntactical rules, and belong to some definite languages, whereas propositions are not composed of words and do not belong to any language." (Pitcher, 1964, p. 28)

To give an example, he says that though the proposition "It is raining." is just one proposition, it can be expressed by three different sentences in three different languages. He adds:

"Propositions are the sort of thing that can be true or false, but sentences cannot be true or false. If someone were to ask "Is the English sentence It is raining'true or false?" one would be at a loss of an answer [...]. It is the proposition [It is raining] which includes a reference to a particular time and place, that is true or false, not the sentence which does not include any such references." (Pitcher, 1964, p. 28)

This apparent difference between propositions and sentences does not look to be right; because in this regard, there is no difference between propositions and sentences, and both of them contain a reference to something. Because of this, both of them will be true or false depending on how things are in the world and whether they match or fail to match the reality they refer to. Using Pitcher's expression, we can say: "if someone were to ask - 'Is the English proposition 'It is raining' true or false?" - one would be at a loss of an answer". In fact, when we are asked whether a proposition or a sentence is true or false, it is granted that the content of it is meant disregarding its state as a proposition or a sentence. To find whether it is true or false, we have to compare it with what it refers to. If Pitcher is right and truth and falsity are properties of just propositions, then there would not be any true or false sentence in any language at all, and this is obviously false. Since for any sentence to be a sentence, it is granted to be either true or false. 
However, we can accept from Pitcher that though Wittgenstein had used Satz in both main meanings of the word, he meant mainly proposition. Moreover, Pitcher refers to what Moore says in "Wittgenstein's Lectures in 1930-33" about this subject. ${ }^{7}$ Moore says that Wittgenstein "sometimes explicitly distinguished sentences and propositions, and sometimes said things which imply that 'sentence' and 'proposition' mean the same" (Moore, 2010, p. 29). Moore says that toward the end of part III (the sign that he uses for the third part of Wittgenstein's lectures), Wittgenstein concluded that "it is more or less arbitrary what we call a proposition" and he confessed that "he could not give a general definition of proposition' any more than of 'game"' (Moore, 2010, p. 261).

Moore, in addition, says that in part II Wittgenstein "had said that the word proposition as generally understood includes both "what I call proposition, also hypotheses, and mathematical propositions'. The distinction between these three kinds is a logical distinction" (Moore, 2010, p. 261), and so in the case of each one, there must be some grammatical rules. Moore says that Wittgenstein had regarded the act of "giving an order" as a proposition while it can be neither true nor false and it can be compared with reality in a sense different from a descriptive proposition (Moore, 2010, p. 262).

By elementary propositions, Wittgenstein means propositions that cannot be analysed further, just as an atomic fact that does not consist of further. The word that he uses for simple things is object. According to him, "a name means an object" (T. 3.203) and "objects are simple" (T. 2.02), and "analysis of propositions must bring us to elementary propositions which consist of names in immediate combination" (T. 4.221).

One problem here is that Wittgenstein sometimes restricts name to simple objects and sometimes speaks of the names of complex things. When he refers to the names of objects, he means naming simple things as if he meant the logical and hypothetical objects and when he refers to the names of complex things, he meant proper names. There are several views on the referents of Wittgenstein's objects. ${ }^{8}$ Some scholars, like Goodman and Frascolla, identify Tractatus objects with qualia, i.e. with abstract entities (universals), whose instances appear in the stream of phenomena (Frascolla, 2004, pp. 369-370). Some others, like Irving Copi and Wilfrid Sellars, held that Wittgenstein's objects are particulars and Wittgenstein's names are names of particulars (Sellars, 1962, p. 9). And some others, like Scott Soames, think that T. 2.02 tells us that there are metaphysically simple objects and they are referents of logically proper names. Soames argues that in T. 2.02 "we are given the ontological counterparts of the two key categories of representational language - proper

Some authors, like Pitcher, Pears, McGuinness and Anscombe, selected the first one, and some others, like Stenius, selected the second one (Pitcher, 1964, p. 28).

7

It should be regarded that those Wittgenstein's lectures are related to the time when some of his views already changed. They correspond to the later period of his thought, and hence are not to be relied upon in reconstructing the theory of meaning contained in Tractatus. Here, we are merely referring to what meanings of these words Wittgenstein had in his mind, of course, in his latter thought.

Only linguistic expressions can possibly have referents. Neither objects, nor states of affairs, nor situations are linguistic expressions - they are the ontological correlates of names, elementary propositions and complex propositions, respectively. Of these three kinds of linguistic expression, only names refer and thus have referents (Bedeutungen), i.e. objects. 
names and atomic sentences" (Soames, 2018, p. 9). However, it is hard to agree with these kinds of identifying because Wittgenstein's point of view requires that the particulars and proper names like "Socrates" and "Plato" are not simple objects, and because of their bodies being complex, strictly speaking, they should be situations.

At the beginning of the first chapter of An Introduction to Wittgenstein's Tractatus, Anscombe quoted from Karl Popper his description of the Tractatus, in which he showed that the elementary propositions of the Tractatus are simple observation statements. She added that the strongest and the sole support that we can find for Popper's account, a rather slender support, is at 3.263:

"The references of primitive signs can be made clear by elucidations. Elucidations are propositions containing the primitive signs. Thus they can only be understood, if one is acquainted with the references of these signs." (T 3.263)

Furthermore, the view that many members of the Vienna Circle accepted and for many years occured in Cambridge discussions was that the elementary propositions are not merely observation statements, but sense-datum statements. Anscombe then goes to reject this interpretation of the book and to show that propositions like "This is a red patch." are not elementary propositions. After referring to some words from Wittgenstein, she argued that in the Notebooks out of which the Tractatus was composed, Wittgenstein "exclaims at the fact that he is absolutely certain that there are elementary propositions, atomic facts, and simple objects, even though he cannot produce one single example" (Anscombe, 1959, pp. 25-29).

\section{Picture Theory of Meaning 9}

Wittgenstein held that though the simple object is not observable and the combination of objects which makes a state of affairs is not as well, but they must be there to provide the ultimate foundation for the construction of language. The connection between language and reality is made by names and objects which make in turn the elementary propositions. ${ }^{10}$ By reducing the complex to the simple, Wittgenstein tries to carry on a classic philosophical enterprise which we find it in Descartes, Leibniz, Locke and Hume (Pitcher, 1964, p. 42).

The relation between the Tractatus and the picture theory of meaning has been stated properly by Anscombe as follows:

"It is sufficiently well known that the Tractatus contains a 'picture theory' of language [...] The whole theory of propositions is, then, on this view, a merely external combination of two theories: a 'picture theory' of elementary propositions (viz. that they have meaning by being 'logical pictures' of elementary states of affairs), and the theory of truth-functions as an account of non-elementary propositions." (Anscombe, 1959, pp. 25-26)

We are told in the Tractatus that the world is composed of "facts" and "situations", which are subdivided into "states of affairs", each of which is a certain configuration of simple objects. There are linguistic entities that correspond to these ontological entities: complex propositions (which can describe facts and situations) are analysable into elementary propositions (which describe possible states of affairs), each of which is a concatenation of names (which stand for simple objects) (Gilbert, 1998, p. 341). So the two parallel structures are equivalent as follows:

language $\leftrightarrow$ world 


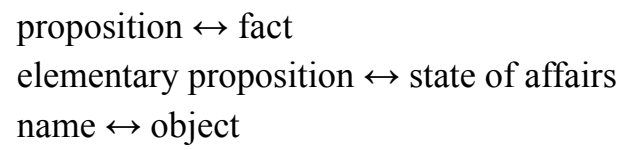

When Wittgenstein speaks of language and world structures, he does not give any example for that structure's components: facts, states of affairs, and objects, on the one hand, and propositions, elementary propositions, and names, on the other. So the function of these concepts is an abstractive function (Grayling, 1988, pp. 28-32).

According to T. 4.024, a proposition is understood when we know what will be the case if it was true. The important difference between the meaning of a name and the meaning of a proposition is that the meaning of a name depends on the object it names (T. 3.203), but the meaning of a proposition depends on the possibility of knowing that in which situation it will be true (T. 4.024). It can be concluded that the meaning of a proposition is independent from it being true or false (Pitcher, 1964, p. 44).

In contrast to Frege, who distincted Sinn from Bedeutung and held that names and sentences can have both of them, Wittgenstein claimed that a name has only Bedeutung and a proposition has only Sinn. A name names an object, and a proposition describes a state of affairs (T. 4.21), and as one elementary proposition is a combination of names, a state of affairs is a combination of objects (T. 2.01; Pitcher, 1964, pp. 45-46).

According to the picture theory, the function of language is to represent or depict reality. It does so by elementary propositions depicting possible states of affairs-they manage to do that by sharing the logical form with the represented states of affairs, i.e., being isomorphic. A proposition must be a picture of a possible situation it depicts whether it was existent or nonexistent. To know the meaning of that proposition, we need to know what situation it depicts:

"A proposition is a picture of reality: for if I understand a proposition, I know the situation that it represents. And I understand the proposition without having had its sense explained to me." (T. 4.021)

The word picture (Bild) is mentioned 68 times in Tractatus and it seems that it does not have a unified meaning (words visual and seeing are mentioned only

Some of the expressions in the Tractatus which shows the picture theory are as follows: "A proposition is a picture of reality: for if I understand a proposition, I know the situation that it represents." (T. 4.021); "A proposition communicates a situation to us and so it must be essentially connected with the situation. And the connection is precisely that it is it's logical picture." (T. 4.03); "Instead of 'This proposition has such and such a sense' we can simply say 'This proposition represents such and such a situation'." (T. 4.031); "One name stands for one thing, another for another thing, and they are combined with one another. In this way the whole group-like a tableau vivant-presents a state of affairs." (T. 4.0311); "The possibility of propositions is based on the principle that objects have signs as their representatives." (T. 4.0312)
10

According to the well-known interpretation of Tractatus, it represents a realist theory of meaning proposing the idea of direct link between bits of language (words) and bits of the world (objects). Given the view, language represents possible states of affairs and this ability of language comes from the links between individual expressions and objects which are existent prior and independent from language. This realist theory of meaning was found in Tractatus by G. E. M. Anscombe, Max Black, A. J. P. Kenny, P. M. S. Hacker, Norman Malcolm and D. F. Pears (see. McGinn, 2006, pp. 4-5; McGinn, 2007, p. 200). 
a few times). We should take into account that there are at least two meanings of a picture in Tractatus, a simple sketch or a doll model (N. 7) and an abstract (logical) picture $(\mathrm{T})$.

However, what Wittgenstein wants to say is that a proposition is a logical picture of a situation, and he is not using the word picture in its ordinary meaning:

"A picture contains the possibility of the situation that it represents." (T. 2.203)

Because an ordinary picture of, for example, a scene looks like the scene, and a proposition does not look like what it describes. So for one proposition, A, to be a logical picture of one situation, $\mathrm{B}$, three conditions must be met:

a) One-to-one correspondence between the components of $\mathrm{A}$ and those of $\mathrm{B}$.

b) Each feature of the structure of A must correspond to a feature of the structure of B. Wittgenstein claimed: "In a proposition there must be exactly as many distinguishable parts as in the situation that it presents. The two must possess the same logical (mathematical) multiplicity." (T. 4.04).

c) Some rules of projection that connect the components of A and those of B.

After referring to these three conditions, Pitcher says that Wittgenstein's example for such rules were rules that connect a musical score to an actual performance of it. Regarding Wittgenstein's interest in music, one might guess that this example had led Wittgenstein to the picture theory of meaning, but it is not the case. Apparently, once Wittgenstein told Von Wright, this idea came to him after reading a report in a magazine (Pitcher, 1964, pp. 78-79). It was during the World War I, and the report was about a model of a car accident that had been presented before a court in Paris. As that model represented the accident by the correspondence between the miniature houses, cars, people, etc., and the real houses, cars, people, etc., it struck Wittgenstein that language can do the same with real things (Monk, 2005, p. 42). ${ }^{11}$

Pitcher mentioned some objections against Wittgenstein's picture theory of propositions.

The first objection is that it is incompatible with some of his other words. Because:

"If a proposition is a picture of a fact, then every word or phrase in it must directly stand for something [...]; and so in the proposition 'the author of Waverly is Scotch', the phrase 'the author of Waverly' must directly represent some object. But according to the theory of definite descriptions, accepted by Wittgenstein, this is not the case." (Pitcher, 1964, p. 80)

Pitcher added that this objection will be swept away by Wittgenstein's insistence that only elementary propositions which consist of names are a picture of situations, and the complex propositions will do this when they are completely analysed into their elementary propositions. If this condition was met, the complex proposition would be a picture of the situation it describes (Pitcher, 1964, pp. 80-81).

In answer to Pitcher, we can say that from the picture theory of meaning, it does not follow that "the author of Waverly" must refer to an object in "the author of Waverly is Scotch". "The author of Waverly" is not a name, as it does not name something simple and indestructible. It is a definite description, which brings in the sentence a complex logical structure, when that sentence is properly analysed (along the Russellian lines - indeed, Wittgenstein acknowledges this debt to Russell in $\S 4.0031$ ). Neither is "Scotch" a Tractarian 
name. It is just not true that if "a proposition is a picture of a fact, then every word or phrase in it must refer to something": this holds only for expressions which figure in a fully analysed form of the sentence, which is obviously not the case with "the author of Waverly is Scotch".

Furthermore, Pitcher claimed that an elementary proposition depicts a situation, but it is not the case; because we know from Wittgenstein, a situation should be reduced to some states of affairs that are relations between objects. So what elementary propositions depict are states of affairs not situations.

The other objection against picture theory, showed by Pitcher several times in his book (Pitcher, 1964, pp. 75-76, 81), is that if an elementary proposition consists of a series of names, how can it state a fact and how can it represent a state of affairs? He wants to say that since a list of names does not make a sentence, it cannot be true or false and cannot picture any state of affairs (Pitcher, 1964, pp. 75-76, 81).

But this objection can be denied too by illustrating that what Wittgenstein had in his mind was that a proposition is a concatenation of names, but it is not a mere concatenation of names like a list (T. 3.141) but as a series of names which are linked and make a sentence. So in this way speaking of a proposition, a bundle of names had been presupposed by him. At the end of the discussion about this subject, Pitcher himself confesses that Wittgenstein speaks of an elementary proposition not as a mere series of names but as a nexus or a connection of names (T. 4.22; Pitcher, 1964, p. 83).

The main problem with Wittgenstein is that he did not give any example for "objects" and "state of affairs", so the picture theory of meaning in him will have just logical meaning and cannot be the basis of the principle of verification which confirms only the scientific propositions. Thus, the descriptiveness of elementary propositions should be regarded as logical descriptiveness, rather than an empirical one.

Picture theory, however, is not necessarily a realistic theory, since there are, no matter how strange, interpretations that say that all this talk of space, time, objects, facts, cases, states of affairs is the talk of these in a logical space with a logical places $(\mathrm{Ort})$. According to these interpretations, all mentions of "reality" are mentions that relate to something "before" the topic of Tractatus, which is logic and meaning, and this seems consistent to the end of it where there is another limit, the one of "something of which we cannot speak of" (T. 7).

\section{Logical Analysis}

Malcolm claimed that once, he asked Wittgenstein whether he had any example for "simple object" in his mind when he was writing the Tractatus. The

In addition to this, it should be regarded that picture-theory is surely influenced also by known concepts of picture by Schopenhauer, and perhaps even more by Hertz and Boltzmann (Preston, 2017, p. 111). This also relates to his concept of model (dynamic model too); since Wittgenstein was regarding a proposition as a model of a situation rather than a picture of it: "A proposition is a model of reality as we imagine it." (T. 4.01) Jacquette has pointed out that though the Tractatus depends on and revels in Schopenhauerian transcendentalism, but in the post-Tractatus period, Wittgenstein gave up transcendentalism in illustrating the conditions for meaningful expressions (Jacquette, 2017, p. 60). 
reply was that at that time he was regarding himself as a logician (Malcolm, 1958, p. 86). So he had no need to mention any example for it.

McGinn says that what gives the elements of representation their meanings is the system of representation, not a direct correlation between name and object and the propositions of ordinary language, when they are used to say something, are logical pictures. In each logical picture, there is nothing in common between the picture and the state of affairs it represents; more than what is common to all pictures that can represent that state of affairs. The facts represented by true propositions exist in logical space and are not prior to or independent of the logical space in which propositions exist. There is one and only one logical space common to language and the reality it describes (McGinn, 2007, pp. 214-217).

In relation to the referents of objects, Wittgenstein says:

"It would be vain to try to express the pseudo-sentence 'Are there simple things?' in symbolic notation. And yet it is clear that I have before me a concept of a thing, of simple correlation, when I talk about this matter. But how am I imaging the simple? Here all I can say is always ' $\mathrm{x}$ has reference'." (N. 45, 6.5.15)

The logical analysis which led Wittgenstein to speak about elementary propositions and simple objects was his thought that if there are complex propositions about real things whose meanings are based on their describing or representing possible facts, the descriptiveness of this kind of propositions is indirectly and through other complex propositions. The question goes to these second complex propositions. If their descriptiveness was indirect, we need some third kind of propositions ad infinitum. In this situation, there would be no understanding and no meaning unless this chain will end in an elementary proposition that depicts something directly, and it cannot be analysed to any other proposition, and it should be a combination of names.

So, according to Wittgenstein's logical analysis, if there was no name, then there was no elementary proposition, and because of that, there was no meaningful proposition at all. The impossibility of an infinite regress in analysing complex propositions persuades us to end the process to elementary propositions consisting of names.

Pitcher showed a conflict in Wittgenstein's view on the sense of propositions: Wittgenstein, on the one hand, thinks that for a proposition in order to have a sense, it must be composed of meaningful terms, and a meaningful term is a word that designates something existent:

"A name means an object. The object is its meaning." (T. 3.203)

This view requires that just true propositions have sense. However, on the other hand, Wittgenstein spoke of the sense of the false propositions and the propositions about mythical and fictitious persons and things:

"A proposition that mentions a complex will not be nonsensical, if the complex does not exist, but simply false.” (T. 3.24)

Pitcher says that this conflict raises grave problems for Wittgenstein (Pitcher, 1964, p. 39). But it seems that there is no conflict in Wittgenstein's view. Pitcher mentions two of Wittgenstein's different views on whether the meanings of propositions depend on their truth or falsity or not. However, what he cited from Wittgenstein's works confirms just the second part of that conflict, and he did not present any citation for the first part. Why should the meaning of a word be related to its designating something existent? In other words, 
what we see in Wittgenstein's word confirms that both true and false propositions have sense. Like a true proposition, a false proposition also consists of names, but the objects these names refer to are not linked together in a state of affairs in a manner their names are concatenated in the considered sentence. It is precisely this which makes the sentence false. We have to concentrate on N. 2.0121 in which Wittgenstein speaks of possibilities, and we should regard objects which are like logical possibilities:

"Logic deals with every possibility and all possibilities are its facts." (N. 2.0121)

The only propositions which can depict real facts are the complex propositions by which certain situations are described. Maybe someone objects that this view is wrong; because if elementary propositions failed to depict reality, so would complex propositions also, as they are nothing but truth-functions of the elementary ones (McGinn, 2006, Ch. 8). The answer is that although a complex proposition is reduced to the elementary propositions of which it is a compound, the difference is that the denoting of the former to the external things is directly and observable while the denoting of the latter is indirectly and unobservable. There is a difference like this in scientific propositions: the difference between the propositions in which empirical terms like extension, colour, are used and the propositions in which theoretical terms like atom and electron are used. We can have an ostensive definition of a stone and not of the atoms which are its components, so the denoting in the first kind of propositions is directly and in the second indirectly and say hypothetically.

\section{Conclusion}

The challenge discussed in this paper was the inconsistency between the positivistic view about the Tractatus and Wittgenstein's logical point of view. According to the positivistic view derived from the Tractatus, only empirical propositions are meaningful because only this kind of propositions depicts the reality and other propositions such as metaphysical propositions and religious propositions have no empirical content. The picture theory of meaning that constitutes the core of the Tractatus says that it is necessary to depict something from the external world for any proposition to have a meaning. Relying on this principle, positivists held that the metaphysical and religious propositions have no meaning and the ethical propositions are expressions of human sensations and emotions.

Additionally, we have the logical aspect of the book in which Wittgenstein, using a logical analysis, claims that the simplest thing in the world is what he calls object. A combination of some objects or, in a strict sense, a relation between some objects makes a state of affairs, and a combination of some states of affairs, in itself, makes a situation. The object is the simplest thing in the world, and we cannot regard something like molecules and atoms as objects because they are complex in themselves. So the problem, in brief, is that if we accept the Vienna Circle view on the picture theory of meaning and the principle of verification as they derived from the Tractatus, which requires the main function of language to be depicting and representing empirical reality, we will have problem with Wittgenstein's objects which cannot be designated and his states of affairs and simple situations will have only logical content, and so, the descriptiveness of elementary propositions from which the complex propositions come will be logical descriptiveness. If we confirm 
the book's logical content, we should look at the picture theory of meaning as a logical view that has nothing to do with empirical reality.

It may be objected that it is quite obvious that the Tractatus contains "logical and not empirical analysis of the world"; however, so do the works of the Vienna Circle positivists. Both Wittgenstein and the members of the Vienna Circle considered the "empirical analysis of the world" the legitimate business of science, not philosophy. In response to this objection, it is to be said that in the Tractatus the debate is on the function of language at all, not just the language of philosophy. Obviously, in philosophy, we are not speaking about empirical realities, but when it is said that the only legitimate and meaningful usage of language is depicting reality, and it is done at the end by elementary propositions, it requires that elementary propositions be empirically verifiable. So what is problematic and controversial is the relation between the elementary propositions which have logical content and the propositions which report the observations and contain empirical content.

\section{Bibliography}

Anscombe, Gertrude Elizabeth Margaret (1959): An Introduction to Wittgenstein's Tractatus, Harper \& Row Publishers, New York.

Ayer, Alfred Jules (1971): Language, Truth and Logic, Penguin Books, London - New York.

Blumberg, Albert E.; Feigl, Herbert (1931): "Logical Positivism: A New Movement in European Philosophy", The Journal of Philosophy 28 (1931) 11, pp. 281-296, doi: https:// doi.org/10.2307/2015437.

Carnap, Rudolf (1959 [1932]): "The Elimination of Metaphysics through Logical Analysis of Language", trans. Arthur Pap, in: Alfred Jules Ayer (ed.), Logical Positivism, Free Press, New York, pp. 60-81.

Conant, James; Bronzo, Silver (2017): "Resolute Readings of the Tractatus", in: HansJohann Glock, John Hyman (eds.), A Companion to Wittgenstein, Wiley-Blackwell, Oxford, pp. 175-194, doi: https://doi.org/10.1002/9781118884607.ch10.

Frascolla, Pasquale (2004): “On the Nature of Tractatus Objects", Dialectica 58 (2004) 3, pp. 369-382, doi: https://doi.org/10.1111/j.1746-8361.2004.tb00311.x.

Gilbert, Christopher(1998): "The Role of Thoughts in Wittgenstein's Tractatus", Linguistics and Philosophy 21 (1998) 4, pp. 341-352, doi: https://doi.org/10.1023/a:1005364300808.

Jacquette, Dale (2017): "Wittgenstein and Schopenhauer", in: Hans-Johann Glock, John Hyman (eds.), A Companion to Wittgenstein, Wiley-Blackwell, Oxford, pp. 59-74, doi: https://doi.org/10.1002/9781118884607.ch3.

Keyt, David (1963): “Wittgenstein's Notion of an Object”, The Philosophical Quarterly 13 (1963), no. 50, pp. 13-25, doi: https://doi.org/10.2307/2217002.

Ludwig, Jan (1976): “'Substance' and 'Simple Objects' in Tractatus 2.02 ff”, Philosophical Studies 29 (1976) 5, pp. 307-318, doi: https://doi.org/10.1007/bf00473440.

Malcolm, Norman (1958): Ludwig Wittgenstein: a Memoir, Oxford University Press, Oxford.

McGinn, Marie (1999): “Between Metaphysics and Nonsense: Elucidation in Wittgenstein's Tractatus", The Philosophical Quarterly 49 (1999), no. 197, pp. 491-513, doi: https://doi. org/10.1111/1467-9213.00155.

McGinn, Marie (2006): Elucidating the Tractatus: Wittgenstein's Early Philosophy of Logic and Language, Oxford University Press, Oxford.

McGinn, Marie (2007): "Simples and the Idea of Analysis in the Tractatus", in: Edward Kanterian, Guy Kahane, Oskari Kuusela (ed.), Wittgenstein and his interpreters. Essays in 
memory of Gordon Baker, Blackwell Publishing, Malden (MA), pp. 200-220, doi: https:// doi.org/10.1002/9780470690963.ch8.

Menger, Karl (1982): “Memories of Moritz Schlick”, in: Gadol, Eugene (ed.), Rationality and Science. A Memorial Volume for Moritz Schlick in Celebration of the Centennial of his Birth, Springer Verlag, Berlin, pp. 83-103.

Monk, Ray (2005): How to Read Wittgenstein, Granta Publication, London.

Moore, George Edward (2010): “Wittgenstein's Lectures in 1930-33”, in: George Edward Moore, Philosophical Papers, London, George Allen \& Unwin, New York, The Macmillan Company.

Morris, Michael (2008): Routledge Philosophy Guidebook to Wittgenstein and the Tractatus, Routledge Taylor \& Francis Group, London - New York.

Peterson, Donald (1990): Wittgenstein's Early Philosophy, University of Toronto Press, Toronto.

Pitcher, George (1964): The Philosophy of Wittgenstein, Prentice-Hall of India, New Delhi.

Preston, John M. (2017): “Wittgenstein, Hertz, and Boltzmann”, in: Hans-Johann Glock, John Hyman (eds.), A Companion to Wittgenstein, Wiley Blackwell, Oxford, pp. 110-123, doi: https://doi.org/10.1002/9781118884607.ch6.

Russell, Bertrand (1956): "The Philosophy of Logical Atomism", in: Robert Charles Marsh (ed.), Logic and Knowledge, The Macmillan Company, New York, pp. 175-281.

Sellars, Wilfrid (1962): "Naming and Saying”, Philosophy of Science 29 (1962) 1, pp. 7-26, doi: https://doi.org/10.1086/287838.

Soames, Scott (2018): The Analytic Tradition in Philosophy: A New Vision, vol. 2, Princeton University Press, Princeton.

Suárez, Alfonso García (2014): “The Metaphysical Status of the Objects of Wittgenstein's Tractatus", Teorema 33 (2014) 2, pp. 29-44.

Weissman, David (1967): "Ontology in the Tractatus", Philosophy and Phenomenological Research 27 (1967) 4, pp. 475-501, doi: https://doi.org/10.2307/2105792.

Wittgenstein, Ludwig (1922): Tractatus Logico-Philosophicus, containing the original text in German, alongside both the Charles Kay Ogden - Frank Plumpton Ramsey, and David F. Pears - Brian McGuinness English translations, Kegan Paul, London. [T]

Wittgenstein, Ludwig (1961): Notebooks 1914-1916, Gertrude Elizabeth Margaret Anscombe, Georg Henrik von Wright (ed.), trans. Gertrude Elizabeth Margaret Anscombe, Blackwell Publishing, Oxford. [N]

Wittgenstein, Ludwig (1971): Prototractatus. An Early Version of Tractatus LogicoPhilosophicus, trans. David F. Pears, Brian McGuiness, Routledge \& Kegan Paul, London. [P] 


\title{
Abdurrazzaq Hesamifar, Alinaqi Baqershahi \\ Wittgensteinov Tractatus i deskriptivnost temeljnih propozicija
}

\begin{abstract}
Sažetak
Prema Wittgensteinovu mišljenju, temeljne propozicije ne mogu se analizirati u daljnje propozicije. U T. 4.22, Wittgenstein govori o imenima kao konstituentima temeljnih propozicija. Što misli pod imenima? Ne misli vlastita imena jer se takva imena referiraju na kompleksna bića. Prema njegovu mišljenju, »ime znači predmet« (T. 3.203), »predmeti su jednostavni« (T. 2.02), a »analiza propozicija mora nas dovesti do temeljnih propozicija koje se sastoje od imena $u$ izravnoj povezanosti« (T. 4.221). Oko deskriptivnosti temeljnih propozicija vodi se spor. Teorija slike, prihvaćena kod ranog Wittgensteina, govori nam o tome da je nužno referirati se na neki izvanjski predmet da bi propozicija imala značenje. Međutim, u Tractatusu, nema oprimjerenja za temeljne propozicije i njihove konstituente, tj. predmete. Stoga, jednadžba između stanja stvari i temeljnih propozicija ili između predmeta i vlastitih imena možda je samo logička jednadžba bez empirijskog sadržaja, usprkos pozitivističkom čitanju Tractatusa koji promovira empirističko tumačenje. Ovaj rad nastoji pokazati da bi, polazeći od teorije slike, temeljne propozicije trebale opisivati nešto u stvarnom svijetu. Bez obzira na to, budući da ono što je njima opisano ne može biti označeno i referirano nikakvom pokaznom definicijom, osim u logičkom smislu riječi, upitan je i kontroverzan način na koji opisuju i predočuju stvarnost.
\end{abstract}

\section{Ključne riječi}

temeljne propozicije, kompleksne propozicije, predmet, stanje stvari, ime, situacija

\section{Abdurrazzaq Hesamifar, Alinaqi Baqershahi \\ Wittgensteins Tractatus und die Deskriptivität der Elementarsätze}

\begin{abstract}
Zusammenfassung
Nach Wittgensteins Dafürhalten lassen sich aufgrund von Elementarsätzen keine weiteren Sätze herausanalysieren. In T. 4.22 redet Wittgenstein von Namen als Bestandteilen der Elementarsätze. Was versteht er unter Namen? Er meint keine Eigennamen, weil solche Namen auf komplexe Wesen verweisen. Seiner Annahme nach ,, bedeutet der Name den Gegenstand “ (T. 3.203), ,, der Gegenstand ist einfach“ (T. 2.02) und „, bei der Analyse der Sätze müssen wir auf Elementarsätze kommen, die aus Namen in unmittelbarer Verbindung bestehen " (T. 4.221). Über die Deskriptivität der Elementarsätze wird ein Disput geführt. Die vom frühen Wittgenstein akzeptierte Theorie der Abbildung besagt, dass es geboten ist, sich auf ein bestimmtes äußeres Ding zu beziehen, um einem Satz eine Bedeutung zu verleihen. Allerdings gibt es in Tractatus keine Verbeispielung für Elementarsätze und deren Bestandteile, d. h. Gegenstände. Dementsprechend ist die Gleichung zwischen Sachverhalten und Elementarsätzen oder zwischen Gegenständen und Eigennamen trotz einer positivistischen Lesart des Tractatus, der einer empirischen Deutung Förderung angedeihen lässt, womöglich lediglich eine logische Gleichung ohne empirischen Inhalt. Dieser Aufsatz intendiert, darauf hinzuweisen, dass die Elementarsätze, ausgehend von der Theorie der Abbildung, etwas in der realen Welt beschreiben sollten. Aber unbeschadet dessen, da jedoch das, was von ihnen beschrieben wird, durch keinerlei demonstrative Definition bezeichnet und referiert werden kann, außer im logischen Sinne des Wortes, ist die Art und Weise, auf die sie die Realität beschreiben und veranschaulichen, fraglich und kontrovers.
\end{abstract}

\section{Schlüsselwörter}

Elementarsätze, komplexe Sätze, Gegenstand, Sachverhalt, Name, Sachlage 


\section{Abdurrazzaq Hesamifar, Alinaqi Baqershahi \\ Le Tractatus de Wittgenstein et le caractère descriptif des propositions élémentaires}

\section{Résumé}

Selon la pensée de Wittgenstein, les propositions élémentaires ne peuvent être analysées dans les propositions suivantes. Dans le T. 4.22, Wittgenstein parle des noms comme des constituants des propositions élémentaires. Qu'entend-il sous le terme de nom? Il ne pense pas aux noms propres car de tels noms se réfèrent à des êtres complexes. Selon lui, «le nom signifie l'objet 》 ( $T$. 3.203), "l'objet est simple » (T. 2.02), et "par l'analyse des propositions, nous devons parvenir à des propositions élémentaires, qui consistent en noms dans une connexion immédiate " (T. 4.221). Le caractère descriptif des propositions élémentaires est un sujet de querelle. La théorie de l'image, acceptée par le jeune Wittgenstein, nous dit qu'il est nécessaire de se référer à un objet extérieur pour que la proposition ait un sens. Toutefois, dans le Tractatus il n'y a pas d'exemplification pour les propositions élémentaires et leurs constituants, à savoir les objets. Dès lors, l'équation entre l'état des choses et les propositions élémentaires ou entre les objets et les noms propres constitue peut-être seulement une équation sans contenu empirique, malgré la lecture positiviste du Tractatus qui met en avant l'interprétation empirique. Ce travail s'applique à montrer que les propositions élémentaires, en partant de la théorie de l'image, devraient décrire quelque chose dans le monde réel. Hormis cela, étant donné que ce qui est décrit par leur entremise ne peut être signifié et se référer à aucune définition démontrable, sauf dans un sens logique, la manière dont ils décrivent le monde et représentent la réalité est incertaine et controversée.

\section{Mots-clés}

propositions élémentaires, propositions complexes, objet, état des choses, nom, situation 